\title{
Derleme
}

Mersin Univ Saglık Bilim Derg 2021;14(1):146-158

doi:10.26559/mersinsbd.709342

\section{Ağır metal maruziyetinde disbiyozis ve probiyotikler}

\author{
Kevser Başoğlu1, (Dylin Ayaz ${ }^{1}$ \\ ${ }^{1}$ Hacettepe Üniversitesi Sağlık Bilimleri Fakültesi Beslenme ve Diyetetik Bölümü,
}

Öz

Modern yaşamda ağır metallerin artan kullanımı, ağır metal maruziyetinde önemli ölçüde artışa sebep olmuştur. Ağır metallerin doğada yüksek kalıcılıkları ve yaygın maruziyet sebebiyle bu durum ağır metal maruziyetini önemli bir halk sağlı̆̆ı problemi haline getirmiştir. Ağır metaller intestinal mikrobiyotanın yapısını ve çeşitliliğini etkileyerek disbiyozise sebep olmaktadır. Ağır metal maruziyetinin sebep olduğu disbiyozisin; oksidatif stres, karaciğer hasarı ve obezite gibi çeşitli sağlık sorunları ile ilişkili olabileceği bildirilmiştir. Probiyotiklerin ağır metallerin neden olduğu hasarı azaltmada, mikrobiyotanın yeniden dengelenmesinde ve sağlığının sürdürülmesinde umut verici olduğu belirtilmektedir. Bu derlemenin amacl, ağır metal maruziyetinin intestinal mikrobiyotaya olası etkilerini, bu etkilerin metabolik sonuçlarını ve probiyotik takviyesinin ağır metal toksisitesini iyileştirme potansiyelini değerlendirmektir.

Anahtar kelimeler: Ağır metaller, halk sağlığı, disbiyozis, probiyotikler

\section{Dysbiosis in heavy metal exposure and the probiotics}

\begin{abstract}
The increasing use of heavy metals in modern life has led to a significant increase in heavy metal exposure. Heavy metals have become an important public health problem due to their high persistence and widespread exposure in nature. Heavy metals cause dysbiosis by affecting the structure and diversity of the intestinal microbiota. Exposure to heavy metals is an important public health problem due to their high persistence and widespread exposure in nature. Dysbiosis in microbiota caused by heavy metal exposure has been reported that it may be associated with various health problems such as oxidative stress, liver damage, and obesity. It is stated that probiotics are promising in reducing the damage caused by heavy metals, rebalancing microbiota and maintaining their health. The purpose of this review is to evaluate the potential effects of heavy metal exposure to the intestinal microbiota, the metabolic results of these effects and the potential of the probiotic supplement to improve heavy metal toxicity.
\end{abstract}

Keywords: Heavy metals, public health, dysbiosis, probiotics

Yazının geliş tarihi: 27.03.2020

Yazının kabul tarihi: 24.01.2021

Sorumlu Yazar: Kevser Başoğlu, Hacettepe Üniversitesi Sağlık Bilimleri Fakültesi Beslenme ve Diyetetik Bölümü, E-posta: basoglukevser@gmail.com 


\section{Giriş}

Ağır metaller toprak, su ve atmosferde çeşitli seviyelerde bulunabilen doğal bileşenlerdir. Son ylllarda madencilik, endüstriyel atıklar, tarımsal faaliyetler gibi insan faaliyetleri sebebiyle ağır metal kullanımında ve dolasıyla insanların ağır metallere maruziyetinde önemli bir artış gözlenmiştir. ${ }^{1}$ Doğada yüksek kalıcılığa sahip olan ağır metaller, insan sağlı̆̆ı üzerinde çeşitli zararlı etkiler gösterebilmektedir. Çinko, bakır, demir, manganez ve kobalt gibi bazı ağır metaller vücudumuz için belirli seviyelerde elzem olmakla birlikte yüksek konsantrasyonlarda toksik etki göstermektedir. Kurşun ve civa gibi bazı ağır metallerin ise insan metabolizmasinda bilinen hiçbir faydası bulunmamakla birlikte vücutta birikimi insan sağlı̆̆ını olumsuz etkilemektedir. İnsanlar bu ağır metallere, kontamine olmuş su ve besinlerden ya da direk çevreden maruz kalmaktadır. Ağır metallere maruziyet; farklı türde kanserler, nörolojik hastalıklar, böbrek fonksiyonlarında hasar, endokrin bozukluklar, merkezi sinir sistemi fonksiyonlarında değișiklikler gibi sağlık problemlerine sebep olduğu için önemli bir sağlık problemi haline gelişmiştir. ${ }^{2}$

İntestinal mikrobiyotamı diş çevreyle aramızda önemli bir ara yüz oluşturmakta ve çevresel toksinlere ilk maruziyet burada gerçekleşmektedir. İntestinal mikrobiyotamız yaklaşık yüz trilyon mikroorganizmalardan oluşan bir süper organizmadır. Vücudumuzdaki mikroorganizmalar, hücre sayısından 10 kat daha fazladır ve bu mikroorganizmaların ürettiği genom ise insan genomundan yüzelli kat daha fazladır. ${ }^{3} \mathrm{Bu}$ mikroorganizma topluluğu çeșitli aktivitelerle ana fizyolojinin düzenlenmesinde temel bir rol oynamaktadır. Günümüzde mikrobiyotanın hastalık ve sağlık üzerinde önemli role sahip olduğu düşünülmektedir. Bağışıklık sisteminin normal gelişimini teşvik ederek; bağırsak geçirgenliği, mukus tabakası ve epitel hücre fonksiyonlarını etkileyerek; beyin-bağırsak ekseni üzerinde çeșitli etkiler göstererek sağlığı etkileyebileceği tahmin edilmektedir. İntestinal mikrobiyotamız sağlıklı olduğunda enfeksiyon ve inflamasyonlara karşı metabolizmayı güçlendirmekte; otoimmün hastalıklara ve kansere karşı koruyucu olarak metabolik regülasyonu düzenleyebilmektedir. Mikrobiyotadaki bozulmalar ise obezite, diyabet, alerjiler ve çeşitli bağırsak hastalıkları gibi hastalıklarla ilişkilendirilmektedir. $\quad \mathrm{Bu}$ sebeple, mikrobiyotayı etkileyen faktörlerin anlaşılması oldukça önemlidir. ${ }^{4}$

Ağır metaller gibi potansiyel toksik maddeler, mikrobiyotaya doğrudan zarar verebilir. Mikrobiyota bu toksik maddeleri, daha az toksik formlara dönüștürerek insanlardaki toksik etkileri azaltma potansiyeline sahiptir. Bununla birlikte eğer bu toksinlere karşı hassasiyet gösteren taksonlar varsa, mikrobiyotadaki değişikliklerin çevresel toksinlere maruz kalmanın biyolojik bir belirteci olarak kullanılabileceği de öne sürülmektedir. Bu gibi sebeplerle mikrobiyotamızın ağır metaller gibi farklı çevresel toksinlerden nasıl etkilendiği ve nasıl etkilediği, bu etkileşimlerin insan sağlığı açısından değeri ve önemi üzerine araştırmalar yapılmıștır. ${ }^{5}$ $\mathrm{Bu}$ derlemede, bazı ağır metallerin mikrobiyotaya etkileri ve bu etkileşimlerin sonuçlarına dair güncel bilimsel verilerin incelenmesi amaçlanmıştır.

\section{Arsenik ve Mikrobiyota}

Sanayide en çok kullanılan metallerden biri olan arsenik (As) birçok bölgede içme suyunda yüksek konsantrasyonlarda bulunduğu için önemli bir halk sağlığı problemi olarak kabul edilmiştir. Dünyada, özellikle Güney ve Doğu Asya'da, milyonlarca insan, Dünya Sağlık Örgütü ve ABD Cevre Koruma Ajansı tarafından olușturulan veya kabul edilen 10 $\mu \mathrm{g} / \mathrm{L}$ sınırını aşan arsenik seviyelerinde su içmektedir. Arsenik maruziyeti cilt, mesane, akciğer ve karaciğer kanserleri diyabet ve kardiyovasküler hastalıklar ile ilișkilendirilmiștir. ${ }^{6}$

Yapılan bir araștırmada minimum arsenik seviyesi olan $10 \mathrm{mg} / \mathrm{L}$ arseniğe dört hafta boyunca maruz kalmanın, farelerde mikrobiyom bileşimini ve metabolik profili önemli ölçüde bozduğu belirlenmiştir. Arsenik maruziyetinin mikrobiyota üzerine etkilerinin araştırıldığı çalışmalar Tablo1'de özetlenmiştir. 
Fareler üzerinde yalnızca arsenik alımını değerlendiren bazı çalışmalarda ${ }^{7,8}$ Firmicutes türlerinde azalış, Bacteroidetes türlerinde artış gözlenirken, arsenik ve demirin birlikte alımını değerlendiren bir başka çalışmada ise ${ }^{9}$ tam tersi sonuçlar gözlenmiştir. Firmicutes türlerinin artması ve Bacteroidetes türlerinin azalması obezlerde sık görülen bir durum olup, karbonhidratlarin daha verimli kullanılmasına sebep olarak enerji eldesi kapasitesinin arttığ bildirilmiştir. İntestinal mikrobiyotadaki değişiklik mikrobiyota metabolitlerinde de değişikliklere sebep olmaktadır. Örneğin glutamin, alanin ve laktat Bacterioidetes ile yüksek pozitif kolerasyon gösterirken, Firmicutes ile negatif kolerasyon gösterdiği; Proteobacteria türleri taurin ile yüksek pozitif kolerasyon gösterirken, asetat ve alanin ile yüksek negatif kolerasyon gösterdiği bulunmuştur. $\mathrm{Bu}$ sebeple arsenik gibi ağır metallerin mikrobiyal toplulukta oluşturduğu değişimler, metabolik profil üzerinde önemli değişikliklere sebep olabilmektedir.

Yapılan bir çalışmada Acidobacteria ve Cyanobacteria türlerinin yalnızca arsenik verilen grupta var olduğu gözlenmiștir. Lactobacillus cinsi ise arsenik+demir verilen gruplarda arttığı, sadece demir verilen grupta ise azaldığı belirlenmiştir. Arsenik ve demire birlikte maruz kalmanın, her bir metalin ayrı ayrı mikrobiyal etkilerinden bazılarını antagonize edebileceği düşünülmektedir. Günlük hayatımızda olduğu gibi birçok metale aynı anda maruz kalındığında bu metaller birbirini etkileyebilmekte ve mikrobiyota üzerinde farklı etkiler gözlenebilmektedir. ${ }^{9}$

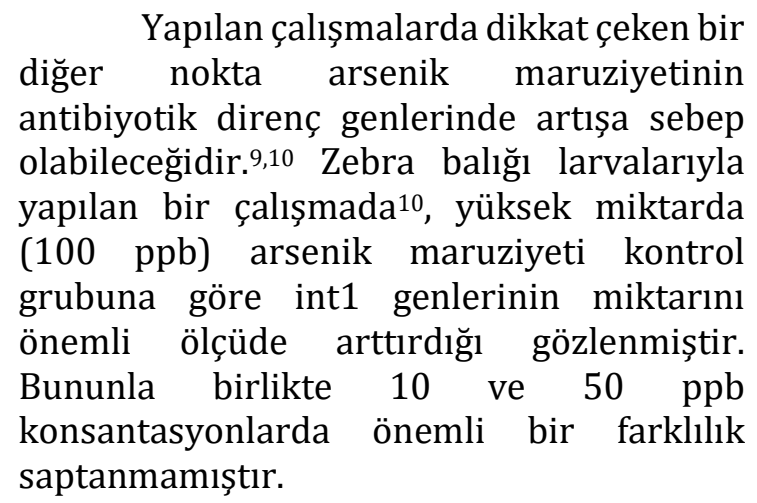

Kurşun ve Mikrobiyota
Kurşun vücudumuz için hiçbir biyolojik fonksiyona sahip olmayan ve ABD Hastalık Kontrol ve Korunma Merkezleri (Centers for Disease Control and Prevention; CDC) tarafından güvenli bir serum seviyesi olmadığı bildirilen son derece toksik bir metaldir. Kurşun maruziyetimiz büyük oranda endüstriyel uygulamalar, sigara, yiyecekler ve içme suyundan kaynaklanmaktadır. Kurşun; hava, toprak, su aracılığ ile vücudumuza girebilmekte ve plasenta yoluyla veya laktasyonla anneden bebeğe $\quad$ geçebilmektedir. ${ }^{1}$ Kurşun maruziyetinin mikrobiyota üzerine etkilerini inceleyen son yıllara ait araștırmalar Tablo2'de özetlenmiştir.

Kurşun

maruziyetinin mikrobiyotada oluşturduğu değişikliklerin arsenikte olduğu gibi metabolik profili etkileyebileceği bildirilmiştir. Kurşun maruziyeti mikrobiyota ile ilişkili olarak; E vitamini, safra asitleri, azot metabolizması, enerji metabolizması, oksidatif stres ve savunma/detoksifikasyon içeren metabolik yollarda bozulma ile ilişkilendirilmiştir. ${ }^{11}$ Zebra balıkları ile yapılan çalışmada yedi gün $30 \mu \mathrm{g} / \mathrm{L}$ kurşun maruziyetinin 41 metaboliti önemli ölçüde değiştirdiği, bunlardan 22'sinin arttı̆̆ 19 'unun azaldığı ve 27 metabolitin glikoz ve lipit metabolizması ile beș metabolitin aminoasit metabolizması ile üç metabolitin ise nükleotit metabolizması ile ilişkili olduğu gösterilmiştir. Ayrıca glikoz ve lipit metabolizması ile ilgili bazı genlerin transkripsiyonunun karaciğerde önemli ölçüde azaldığı belirlenmiştir. ${ }^{12}$

Aynı çalışmada kurşun maruziyetinin ardından mukus salgılanmasında bir artış olduğu tespit edilmiş, kurşun maruziyetinin goblet hücrelerine ve dolayısıyla bağırsak bariyer fonksiyonlarına zarar verdiği ileri sürülmüştür. ${ }^{12}$ Mukus intestinal mikrobiyota için yaşam alanı sağlar ve özellikle 'mukofilik' bakteriler için oldukça önemlidir. Akkermansia muciniphila mukus tabakasının oluşmasına yardımcı olan önemli bir bakteri olup, kurşun maruziyetinden sonra mikrobiyotada tespit edilmemiştir. ${ }^{13}$

Kurşun maruziyeti aynı zamanda vücut ağırlığında artış ile ilişkili bulunmuştur.13,14 Kurşun maruziyetinin sebep olduğu intestinal mikrobiyotadaki 
değişiklikler yetişkin erkek farelerde vücut ağırlığı ile yüksek derecede ilişkili bulunmuştur. Erkek farelerde \%11 ağırlık artışına sebep olduğu ve bu artışın anlamlı olduğu bildirilmiștir. Bununla birlikte diși farelerde anlamlı bir fark gözlenmemiştir. Perinatal dönemde kurşun maruziyeti yaşamış yavrularda, erişkin intestinal mikrobiyotasının artan Firmicutes/Bacteroidetes oranı ile ilişkilendirilmiş ve bu orandaki artışın obezite ile ilişkilendirilmesi de aradaki ilişkiyi kuvvetlendirmektedir. ${ }^{13}$ Kurşun maruziyeti ile neredeyse tamamen tükenen Akkermansia türlerinin son zamanlarda abdominal yağlanma ve iltihaplanmaya karşı kısmen koruyucu olduğunun kanıtlanması da yine aradaki ilişkiyi kuvvetlendirmektedir. ${ }^{15}$

\section{Kadmiyum ve Mikrobiyota}

Kadmiyum, ABD Toksik Maddeler ve Hastalık Kayıt Ajansı (ATSDR) sıralamasına göre yedinci en toksik ağır metaldir. Özellikle şarj edilebilir pillerde, metal kaplamalarda, boya endüstrisinde pigment olarak, plastik dengeleyicilerde sıklıkla kullanılmaktadır. Kadmiyum solunum ve yutma yoluyla vücudumuza girebilmekte ve yaşam süresince vücudumuzda birikmektedir. Sanayi faaliyetlerinin fazla olduğu bir bölge olan Çin'de kadmiyumun kirlettiği toplam alanın 11.000 hektardan fazla olduğu ve çevreye atılan yıllık endüstriyel kadmiyum atı̆̆ının 680 tondan fazla olduğu

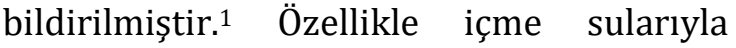
kadmiyuma maruziyet küresel anlamda önemli bir sağlık problemi olarak görülmektedir. Kadmiyum maruziyeti; nörotoksik etkiler, böbrek hasarı, meme/prostat/böbrek kanseri, üreme problemleri, kemik demineralizasyonu ve diyabet gibi çok çeşitli sağlık sorunlarıyla ilişkilendirilmektedir. ${ }^{2}$

\section{Kadmiyumun}

toksisitesinin mekanizması tam olarak anlaşılamamakla birlikte mikrobiyotanın toksisiteye karşı nasıl bir rol üstlendiği merak konusudur. Kadmiyum ve mikrobiota ilişkisini incelen son yıllarda yapılan çalışmaların bir kısmı Tablo 3'te özetlenmiştir. Tablo 3'te verilen çalışmalarda kadmiyum maruziyetinin, intestinal mikrobiyota yapısında ve çeşitliliğinde önemli ölçüde bozulmaya neden olduğu görülmektedir, bununla birlikte hangi türlerin artıp hangilerinin azaldığı konusunda ise çelişkili sonuçlar vardır. Örneğin yapılan bir çalışmada hem kadmiyum hem kurşun Lachnospiraceae bolluğunu artırmıştır. ${ }^{14}$ Başka bir çalışmada ise Firmicutes/Bacteroidetes oranında azalma gözlenirken, bir haftalık kadmiyum maruziyetinin Bifidobacterium ve Lactobacillus popülasyonunu anlamlı olarak azalttığı, TNF- $\alpha$ üretiminin arttığ ve kısa zincirli yağ asitlerindeki değişikliklerde eş zamanlı gerçekleşmiştir. Buna karşın sekiz hafta $\mathrm{Cd}$ maruziyeti uygulanan benzer bir çalışmada Bacteroidetes bolluğu önemli ölçüde azalmış, Verrucomicrobia ise artmış ve dışkıda kısa zincirli yağ asiti konsantasyonunda azalma olduğu gözlenmiştir. $\mathrm{Bu}$ çalışmada aynı zamanda çözünmez posanın $\mathrm{Cd}$ maruziyetine karşı koruyucu etkisi değerlendirilmiş ve sekiz hafta $\mathrm{Cd}$ maruziyeti ile birlikte diyetlerine çözünmez posa eklenmiştir, bu grupta $\mathrm{Cd}$ maruziyetinin anlamlı olarak azaldığı ve dışkıda kısa zincirli yağ asiti konsantrasyonunda artış olduğu gözlenmiştir. Çözünmez posanın daha emilmeden kadmiyuma bağlanarak dışkı ile atılmasını sağladığı ve kadmiyum maruziyetinden korumada önemli bir rol üstlendiği ileri sürülmüştür. ${ }^{16}$

Cd maruziyeti ile değişen mikrobiyotanın, serum lipopolisakkarit seviyelerinde bir artışa neden olabileceği ve dolaylı olarak $\mathrm{Cd}$ maruziyetinden sonra enerji homeostazında bozulmalara neden olabilen hepatik inflamasyonun gelişebileceği ileri sürülmüştür. ${ }^{17}$ Ayrıca kadmiyum maruziyetinin iltihabi reaksiyonlara ve sıkı bağlantı noktalarında gevşemelere sebep olduğu ve böylece bağırsak geçirgenliğini arttırdığı bildirilmiştir. Artan lipopolisakkarit üretimi ve bağırsak bariyer fonksiyonlarındaki bozulma birlikte düşünüldüğünde endotoksemi ve sistemik inflamasyon oluşacaktır. Bir varsayım olarak Cd'a maruziyetin, bakteriyel translokasyonun artmasına sebep olacağı düşünülmektedir.18 
Tablo1. Arsenik maruziyeti ve instestinal mikrobiyotaya etkileri

\begin{tabular}{|c|c|c|c|c|c|}
\hline Çalışma Türü & $\begin{array}{l}\text { Örneklem } \\
\text { Grubu }\end{array}$ & $\begin{array}{l}\text { Uygula } \\
\text { ma } \\
\text { Süresi }\end{array}$ & Yöntem & Sonuçlar & Kaynak \\
\hline $\begin{array}{l}\text { Kontrollü Klinik } \\
\text { Çalışma }\end{array}$ & $\begin{array}{l}\text { C57BL /6 dişi } \\
\text { faresi } \\
\text { (10 fare/grup) }\end{array}$ & 4 hafta & $\begin{array}{l}\text { İçme suyunda } 10 \text { ppm inorganik } \\
\text { As ile muamele }\end{array}$ & $\begin{array}{l}\text {-İnstestinal mikrobiyom kompozisyonunda } \\
\text { önemli ölçüde bozulma } \\
\text { - Firmicutes'lerde azalma } \\
\text { •Bacteroidetes'lerde artma }\end{array}$ & $\begin{array}{l}\text { Lu K. ve ark. } \\
(2014)^{7}\end{array}$ \\
\hline $\begin{array}{l}\text { Kontrollü Klinik } \\
\text { Çalışma }\end{array}$ & $\begin{array}{l}\text { C57BL/6 diși fare } \\
\text { ve IL10 -/- } \\
\text { fareler } \\
\text { (10 fare/grup) }\end{array}$ & 4 hafta & $\begin{array}{l}\text { İçme suyunda } 10 \text { ppm inorganik } \\
\text { As ile muamele }\end{array}$ & $\begin{array}{l}\text {-Firmicutes'lerde bir azalma } \\
\text { • Bacteroidetes'lerde bir artma }\end{array}$ & $\begin{array}{l}\text { Lu K. ve ark. } \\
(2014)^{8}\end{array}$ \\
\hline $\begin{array}{l}\text { Kontrollü Klinik } \\
\text { Çalışma }\end{array}$ & $\begin{array}{l}\text { ICR faresi } \\
\text { (10 fare/grup) }\end{array}$ & 90 gün & $\begin{array}{l}\text { İçme suyunda; As ( } 3 \mathrm{mg} / \mathrm{L}) \\
\text { demir }(5 \mathrm{mg} / \mathrm{L}) \text { ve her ikisi ile } \\
\text { muamele }\end{array}$ & $\begin{array}{l}\text { Her iki metal maruziyetinde de; } \\
\text { - Firmicutes, Tenericutes, Proteobacteria'nın } \\
\text { göreceli bolluğunda bir artma } \\
\text { - Bacteroidetes ve TM7'de azalma } \\
\text {-Antibiyotik direnç genlerinde artma }\end{array}$ & $\begin{array}{l}\text { Guo, X ve } \\
\text { ark. } \\
(2014)^{9}\end{array}$ \\
\hline $\begin{array}{l}\text { Kontrollü Klinik } \\
\text { Çalışma }\end{array}$ & $\begin{array}{l}\text { Et20 suşu zebra } \\
\text { balığı larvaları } \\
(30-60 \\
\text { zebrabalığı })\end{array}$ & 20 gün & $\begin{array}{l}\text { Suda } 10,50,100 \mathrm{ppb} \text { inorganik As } \\
\text { ile muamele }\end{array}$ & $\begin{array}{l}\text {-Acinetobacter, Sediminibacterium, } \\
\text { Janthinobacterium'da artma } \\
\text { - Bdellovibrio, Pseudomonas azalma } \\
\text {-Antibiyotik direnç genlerinde (int1) artma }\end{array}$ & $\begin{array}{l}\text { Dahan D. ve } \\
\text { ark. } \\
(2018)^{10}\end{array}$ \\
\hline $\begin{array}{l}\text { Kontrollü Klinik } \\
\text { Çalışma }\end{array}$ & $\begin{array}{l}\text { C57BL/ } 6 \text { erkek } \\
\text { ve dişi fare } \\
\text { (10 fare/grup) }\end{array}$ & 4 hafta & $\begin{array}{l}\text { İçme suyunda } 10 \text { ppm inorganik } \\
\text { As ile muamele }\end{array}$ & $\begin{array}{l}\text { •Dorea spp'nin dişi farelerde azalışı erkek } \\
\text { farelerde artma } \\
\text { •Akkermansia spp. için sadece dişi farelerde } \\
\text { önemli ölçüde artma }\end{array}$ & $\begin{array}{l}\text { Chi L. ve } \\
\text { ark. } \\
(2016)^{37}\end{array}$ \\
\hline $\begin{array}{l}\text { Kontrollü Klinik } \\
\text { Çalışma }\end{array}$ & $\begin{array}{l}\text { Caco-2 and HT29- } \\
\text { MTX hücre } \\
\text { kültürleri }\end{array}$ & 72 saat & $1 \mathrm{uM}-10 \mathrm{uM}$ inorganik As & $\begin{array}{l}\text {-Mukusta inorganik arsenik birikimi } \\
\text { •Hücresel arsenik alımında azalma }\end{array}$ & $\begin{array}{l}\text { Calatayud } \\
\text { M. ve ark. } \\
\text { (2012) } 38\end{array}$ \\
\hline
\end{tabular}


Tablo2. Kurșun maruziyeti ve instestinal mikrobiyotaya etkileri

\begin{tabular}{|c|c|c|c|c|c|}
\hline $\begin{array}{l}\text { Çalışma } \\
\text { Türü }\end{array}$ & $\begin{array}{l}\text { Örneklem } \\
\text { Grubu }\end{array}$ & $\begin{array}{l}\text { Uygulama } \\
\text { Süresi }\end{array}$ & Analiz Yöntemi & Sonuçlar & Kaynak \\
\hline $\begin{array}{l}\text { Kontrollü } \\
\text { Klinik } \\
\text { Çalışma }\end{array}$ & $\begin{array}{l}\text { C57BL / } 6 \text { dişi } \\
\text { fareleri } \\
\text { (5 fare/grup) }\end{array}$ & 13 hafta & $\begin{array}{l}\text { İçme suyunda } 10 \\
\text { ppm } \mathrm{PbCl}_{2}{ }^{\prime} \text { ye } \\
\text { maruziyet }\end{array}$ & $\begin{array}{l}\text {-Clostridiales, Ruminococcus spp., Ruminococcaceae, } \\
\text { Oscillospira spp. türlerinde azalma } \\
\text { •E vitamini, safra asitleri, azot metabolizması, enerji } \\
\text { metabolizması, oksidatif stres ve savunma / detoksifikasyon } \\
\text { içeren metabolik yollar bozulma }\end{array}$ & $\begin{array}{l}\text { Gao B. ve } \\
\text { ark. } \\
(2017)^{11}\end{array}$ \\
\hline $\begin{array}{l}\text { Kontrollü } \\
\text { Klinik } \\
\text { Çalışma }\end{array}$ & $\begin{array}{l}A B \text { suşu erkek } \\
\text { zebra balığı } \\
\text { (Danio rerio) } \\
\text { (18 balık/grup) }\end{array}$ & 7 gün & $\begin{array}{l}\text { Suda } 10 \text { ve } 30 \\
\mu \mathrm{g} / \mathrm{L} \mathrm{Pb} \text { maruziyet }\end{array}$ & $\begin{array}{l}\text { - a-Proteobakteri türlerinde azalma } \\
\text {-Firmicutes türlerinde artma } \\
\text {-Mukus sekresyonunda artma } \\
\text {-Hepatik metabolik bozukluk }\end{array}$ & $\begin{array}{l}\text { Xia J. ve ark. } \\
(2018)^{12}\end{array}$ \\
\hline $\begin{array}{l}\text { Kontrollü } \\
\text { Klinik } \\
\text { Çalışma }\end{array}$ & $\begin{array}{l}A \text { vy suşu vahşi } \\
\text { tip }(a / a) \\
\text { fareler } \\
13 \text { (4 dişi ve } 9 \\
\text { erkek) kontrol } \\
\text { grubu ve } 15(7 \\
\text { dişi ve } 8 \text { erkek) } \\
\text { deney grubu }\end{array}$ & 40 hafta & $\begin{array}{l}\text { Gestasyon ve } \\
\text { laktasyon } \\
\text { dönemlerinde } \\
\text { içme suyuyla } \mathrm{Pb} \\
\text { asetat ( } 32 \mathrm{ppm} \text {, } \\
\text { ortalama kan } \\
\text { kurşun seviyesi } 32 \\
\mu \mathrm{g} / \mathrm{dL} \text { ) }\end{array}$ & $\begin{array}{l}\text {-Yüksek Firmicutes /Bacteroidetes oranı } \\
\text {-Desulfovibrionaceae, Barnesiella, Clostridium XIVb'de artma } \\
\text {-Lactococcus, Enterorhabdus, Caulobacterales'de azalma } \\
\text {-Erkek yavrularda erişkin dönemde vücut ağırlığında artışla } \\
\text { anlamlı ilişkili fakat dişi yavrularda değil }\end{array}$ & $\begin{array}{l}\text { Wu J. ve ark. } \\
(2016)^{13}\end{array}$ \\
\hline $\begin{array}{l}\text { Kontrollü } \\
\text { Klinik } \\
\text { Çalışma }\end{array}$ & $\begin{array}{l}25 \text { Balb / C dişi } \\
\text { faresi }\end{array}$ & 8 hafta & $\begin{array}{l}\text { İçme suyunda } \\
\text { kurşun }\left(\mathrm{PbCl}_{2}, 100\right. \\
\text { veya } 500 \mathrm{ppm}) \\
\text { veya kadmiyuma } \\
\left(\mathrm{CdCl}_{2}, 20 \text { veya }\right. \\
100 \mathrm{ppm}) \\
\text { maruziyet }\end{array}$ & $\begin{array}{l}\text {-Mikrobiotadaki değişimler ile erkeklerde erişkin vücut } \\
\text { ağırlı̆̆ındaki artış arasında ilişki } \\
\text { •Her iki ağır metale de maruziyetinde Lachnospiraceae } \\
\text { sayısında azalma }\end{array}$ & $\begin{array}{l}\text { Breton J. ve } \\
\text { ark. } \\
(2013)^{14}\end{array}$ \\
\hline
\end{tabular}


Tablo 3. Kadmiyum maruziyeti ve instestinal mikrobiyotaya etkileri

\begin{tabular}{|c|c|c|c|c|c|}
\hline Çalışma Türü & $\begin{array}{l}\text { Örneklem } \\
\text { Grubu }\end{array}$ & $\begin{array}{l}\text { Uygulama } \\
\text { Süresi }\end{array}$ & Analiz Yöntemi & Sonuçlar & Kaynak \\
\hline $\begin{array}{l}\text { Kontrollü } \\
\text { Klinik Çalışma }\end{array}$ & $\begin{array}{l}\text { ICR dişi faresi } \\
\text { (10 fare/grup) }\end{array}$ & 8 hafta & $\begin{array}{l}100 \text { mg L Cd } \\
\text { maruziyeti ve/veya } \\
\% 10 \text { buğday kepeği }\end{array}$ & $\begin{array}{l}\text { - Bacteroidetes türlerinde azalma } \\
\text {-Kısa zincirli yağ asitlerinde azalma(yalnızca } \\
\text { Cd maruziyetinde) } \\
\text {-Buğday kepeği ile Cd toksisitesini azalma } \\
\text { potansiyeli }\end{array}$ & $\begin{array}{l}\text { Li Y. ve ark. } \\
(2016)^{16}\end{array}$ \\
\hline $\begin{array}{l}\text { Kontrollü } \\
\text { Klinik Çalışma }\end{array}$ & $\begin{array}{l}\text { C57BL/6 erkek } \\
\text { fareleri } \\
\text { (8 fare/grup) }\end{array}$ & 10 hafta & $\begin{array}{l}\text { İçme suyunda; } 1,3 \text { ve } \\
10 \mathrm{mg} / \mathrm{L} \mathrm{Cd} \\
\text { maruziyeti }\end{array}$ & $\begin{array}{l}\text {-Firmicutes, Y-Proteobacteria türlerinde } \\
\text { azalma } \\
\text { •Bacteroidetes türünde artma } \\
\text { •Hepatik inflamasyon, enerji metabolizması } \\
\text { düzensizliği }\end{array}$ & $\begin{array}{l}\text { Zhang S. ve ark. } \\
(2015)^{17}\end{array}$ \\
\hline $\begin{array}{l}\text { Kontrollü } \\
\text { Klinik Çalışma }\end{array}$ & $\begin{array}{l}\text { C57BL / 6J } \\
\text { fareleri } \\
\text { (4-6 fare/grup) }\end{array}$ & 20 hafta & $\begin{array}{l}\text { Maternal farelere } \\
\text { gestasyon dönemi } \\
\text { boyunca içme suyunda } \\
0.02-500 \mathrm{nM} \\
\text { aralığında bir dizi Cd } \\
\text { maruziyeti }\end{array}$ & $\begin{array}{l}\text {-Tür çeşitliliğinde azalma } \\
\text { •Hepatik lipid metabolizmasında hızlanma } \\
\text { Erkek farelerde; } \\
\text { •Bifidobacterium ve Prevotella türlerinde } \\
\text { azalma } \\
\text { •Artan yağlanma ile iliş̧ki }\end{array}$ & $\begin{array}{l}\text { Ba Q. ve ark. } \\
(2017)^{20}\end{array}$ \\
\hline $\begin{array}{l}\text { Kontrollü } \\
\text { Klinik Çalışma }\end{array}$ & $\begin{array}{l}\text { Wistar erkek } \\
\text { Sıçan } \\
\text { (6 fare/grup) }\end{array}$ & 21 gün & $\begin{array}{l}\text { Grup2: } 200 \mu \mathrm{g} / \mathrm{mL} \mathrm{Cd} \text {, } \\
\text { Grup3: } \% 5 \text { inülin+ L. } \\
\text { plantarum + Cd, } \\
\text { Grup4: } \% 5 \text { inülin+ B. } \\
\text { coagulans+ Cd }\end{array}$ & $\begin{array}{l}\text {-Anaeorobik, aerobik ve laktik asit bakterinde } \\
\text { azalma } \\
\text { •Kadmiyum grubunda vücut ağırlığında } \\
\text { anlamlı bir azalma }\end{array}$ & $\begin{array}{l}\text { Jafarpour D.ve } \\
\text { ark. } \\
(2015)^{21}\end{array}$ \\
\hline $\begin{array}{l}\text { Kontrollü } \\
\text { Klinik Çalışma }\end{array}$ & $\begin{array}{l}\text { Balb /c fareleri } \\
\text { (10 fare/grup) }\end{array}$ & 21 gün & $\begin{array}{l}\text { İçme suyunda } 20 \text { ve } \\
100 \mathrm{mg} \mathrm{kg-1} \mathrm{Cd} \\
\text { maruziyeti }\end{array}$ & $\begin{array}{l}\text {-Lactobacillus ve Bifidobacterium türlerinde } \\
\text { azalma } \\
\text {-Firmucutes/Bacteroidetes oranında azalma } \\
\text {-Kısa zincirli yağ asitlerinde önemli azalma } \\
\text {-Kolonik TNF-a'da önemli ölçüde artıș }\end{array}$ & $\begin{array}{l}\text { Liu Y. ve ark. } \\
\text { (2014) }{ }^{39}\end{array}$ \\
\hline
\end{tabular}


Tablo 3'ün devamı

\begin{tabular}{|c|c|c|c|c|c|}
\hline Çalışma Türü & $\begin{array}{l}\text { Örneklem } \\
\text { Grubu }\end{array}$ & $\begin{array}{l}\text { Uygulama } \\
\text { Süresi }\end{array}$ & Analiz Yöntemi & Sonuçlar & Kaynak \\
\hline $\begin{array}{l}\text { Kontrollü } \\
\text { Klinik Çalışma }\end{array}$ & $\begin{array}{l}\text { C57black/6 } \\
\text { fareleri } \\
\text { (10 fare/grup) }\end{array}$ & 8 hafta & $\begin{array}{l}\text { İçme suyunda } \\
100 \mathrm{mg} / \mathrm{L} \mathrm{Cd} \\
\text { maruziyeti }\end{array}$ & $\begin{array}{l}\text {-Alistipes ve Odoribacterlerib türlerinin göreceli } \\
\text { bolluğunda artma } \\
\text {-Mollicutesler ve Ruminococcaceae türlerinde } \\
\text { azalma } \\
\text { •Akkermansia türünde önemli azalma }\end{array}$ & $\begin{array}{l}\text { Zhai Q., ve ark. } \\
(2017)^{24}\end{array}$ \\
\hline $\begin{array}{l}\text { Randomize } \\
\text { Kontrollü } \\
\text { Klinik Çalışma }\end{array}$ & $\begin{array}{l}\text { Balb/c fareleri } \\
\text { (10 fare/grup) }\end{array}$ & 45 gün & $\begin{array}{l}\text { İçme suyunda } 23 \\
\text { ila } 50 \text { mg kg- } 1 \\
\text { aralığında bir } \\
\text { dizi Cd } \\
\text { maruziyeti }\end{array}$ & $\begin{array}{l}\text {-B. cereus, Lactobacillus spp, Clostridium spp, E. coli } \\
\text { türlerinde azalma } \\
\text { •Bütün mikrobiyal türlerin popülasyonunda } \\
\text { keskin bir azalma }\end{array}$ & $\begin{array}{l}\text { Fazeli M. ve } \\
\text { ark. } \\
(2011)^{40}\end{array}$ \\
\hline
\end{tabular}


Yapılan bir çalışmada yirmi sekiz gün boyunca içme suyu ile düşük dozda kadmiyum alan farelerde bakteri çeşitliliğinde önemli bir azalma, Firmicutes/Bacteroidetes oranında değişiklikler belirlenmiştir. Bununla birlikte NF- $\kappa$ B yolunun aktivasyonu ve proinflamatuar sitokinlerde artış gözlenmiştir. Ayrıca germ-free farelerde de daha düşük derecede olsa da aynı etkiler gözlenmiş, kadmiyum maruziyetinin etkilerinin intestinal mikrobiyomdan kısmende olsa bağımsız olabileceği düşünülmüştür. ${ }^{19}$

Gestasyon öncesi düşük doz kadmiyum maruziyetinin yetişkin dönemde obeziteye katkısını araştıran bir çalışmada, kadmiyuma maruz kalmanın hepatik gen profilini bozabileceği, hepatik lipit metabolizmasını etkileyebileceği ve erișkin dönemde anormal yă birikimine sebep olabileceği ileri sürülmüștür. Gestasyon öncesi $100 \mathrm{nM}$ kadmiyuma yedi gün maruz kalma, erkek farelerde artan yağlanma ile ilişkili bulunmuş, fakat aynı etki dişi farelerde gözlenmemiştir. ${ }^{20}$ Başka bir çalışmada ise kadmiyum maruziyeti vücut ağırlığında azalma ile ilişkili bulunmuştur. ${ }^{21}$ Çalışmalardan net bir sonuç çıkarabilmek için daha çok çalışmaya ihtiyaç duyulmaktadır.

\section{Diğer bazı ağır metal maruziyetleri ve Mikrobiyota}

Krom, yer kabuğunda yaygın bulunan bir mineral olup, antropojenik kaynaklardan çevreye salınabilmektedir. İçme suyu ve yiyecek yoluyla hekzavalent krom (Cr (VI)) alımının toksisitesine bağlı olarak ciddi hastalıklara neden olduğu belirlenmiştir. Farelerde yedi hafta $2 \mathrm{mM}$ krom (Cr) maruziyetinin; Paraprevotellaceae ve Bacteroidetes türlerinde artış, Firmicutes, Lachnospiraceae ve Tenericutes türlerinde azalışa sebep olduğu gösterilmiştir. $\mathrm{Bu}$ değişimlerle bağlantılı olarak ortaya çıkan disbiyozis, oksidatif stres ve karaciğer hasarı ile ilişkilendirilmiştir.22

Civa $(\mathrm{Hg})$ çevrede çeşitli kimyasal formlarda bulunan başka bir ağır metaldir. Toplumsal olarak, diyet bu kirleticiye maruz kalmanın ana yoludur. İnorganik civa veya metil civaya maruz kalmanın; mukusta civa birikimini arttırdığı, intestinal permabilitede görünür bir artışa sebep olduğu bildirilmiştir. $^{23}$ Subkronik oral $\mathrm{Cu}$ ve alüminyum sekiz hafta maruziyetinin farelerde bağırsak mikrobiyal çeşitliliğinde keskin bir düşüşe sebep olduğu, Alistipes, Bacteroidetes, Allobaculum gibi türlerin bolluğunu değiştirdiği, Akkermansia türünde ise önemli ölçüde azalmaya sebep olduğu bildirilmiştir. ${ }^{24}$

Yapılan bir çalıșmada, beș gün boyunca üç doz kobalt, krom, nikel, arsenik ve kadmiyum oral gavaj yoluyla verilmiștir. Genel olarak metal maruziyetinden sonra mikrobiyom bileşimindeki değişikliklerin metale özgü olduğu görülmüştür. Nikel, arsenik ve kadmiyum maruziyetinin intestinal mikrobiyota kompozisyonunu önemli ölçüde değiștirdiği, krom ve kobaltın ise daha hafif etkiler gösterdiği belirlenmiştir. Kobalt ve krom maruziyetinden kaynaklanan mikrobiyota değişikliği güçlü olmamasına rağmen, bu maruziyetlerin ağırlıkta azalmaya, karaciğerde ve böbrekte metal birikimine sebep olduğu bildirilmiştir. ${ }^{25}$

Çevresel kimyasallara maruziyet, konakçının genetik/epigenetik/fenotipik özellikleri ve gut mikrobiyom değişiklikleri arasında güçlü bir ilişki vardır. Çevresel kimyasallar fenotipik değişikliklere ve mikrobiyotada değişmeye neden olmaktadır. $\mathrm{Bu}$ fenotipik değişikliklere obezite, GIS hastalıkları, hormonal değişiklikler örnek verilebilir. Çevresel kimyasallar disbiyozise doğrudan da neden olabilmektedir. Disbiyosiz immünolojik ve metabolik yollarla epigenetik/fenotipik özellikleri değiştirebildiği gibi çevresel toksik maddelerin emilim, dağıtım, metabolizma ve atımını da değiştirebilmektedir. Bu üçlü arasında çift yönlü ilișki vardır ve gerçekte hangisinin hangisine sebep olduğunu tahmin etmek zordur. ${ }^{26}$

\section{Probiyotiklerin ağır metal toksisitesi üzerine etkisi}

Yeterli miktarda takviye edildiğinde insan sağlığına fayda sağlayan probiyotikler 
gıda kaynaklı kirleticilere karşı koruma için umut verici bir araç olarak görülmektedir. Kanitlar bazı probiyotiklerin akut ve kronik ağır metal toksisitesini hafifletebileceğini, organizmaları pestisitlerin toksisitesine karşı koruyabileceğin, antibiyotiklerin diyare ile ilişkili riskini azaltabileceğini ve bu sayede intestinal mikrobiyotanın yeniden dengelenmesini sağlayabileceğini göstermektedir. ${ }^{27,28,29}$

Probiyotikler ağır metallerin sistemik dolaşıma geçmesini önleyerek dokularda oksidatif stresin azalmasında ve doku hasarının hafiflemesinde etkili olabilirler. Lactobacillus türleri ağır metal toksisitesini azaltmak için sıklıkla kullanılan bir türdür. Lactobacillus ağır metalleri bağlama kapasitesine sahip olup, ağır metal birikimini önemli ölçüde azaltabilmektedir. ${ }^{27}$ Yapılan bir çalışmada tek doz (1.8 mg) oral kadmiyuma maruz kalmıș farelere yedi gün boyunca $1 \times 10^{9} \mathrm{CFU}$ L. Plantarum CCFM8610 verilmiștir. $L$. Plantarum CCFM8610 uygulamasinin kadmiyum maruziyeti sonrasında görülen sıkı bağlantı proteinlerinin (ZO-1, ZO-2, okludin ve Klaudin-1) mRNA ekspresyonundaki azalmaları, sistemik dolaşıma kadmiyum sızıntılarındaki artışı, azalmış bağırsak permabilitesini tersine çevirdiği belirlenmiștir. Böylece bazı probiyotik suşlarının gastrointestinal peristaltizmi destekleyebileceği, dolayısıyla dışkıda ağır metallerin atımını kolaylaştırabileceği ve hatta intestinal bariyer fonksiyonunu artırarak ve ince bağırsak epitelinin sıkı birleșim noktalarını düzenleyerek ağır metallerin girişini sınırlayabileceği gösterilmiştir. ${ }^{28}$

Probiyotiklerin oksidatif strese karşı koruyucu bir rol üstlenerek doku hasarını azalttığına dair yapılan bir başka çalışmada ratlar onaltı gün süreyle $1.0 \mathrm{mg} / 100 \mathrm{~g}$ dozunda arseniğe maruz bırakılmıștır. Arsenik maruziyeti ile birlikte lipit peroksidasyon ürünlerinde ve NF- $\kappa \mathrm{B}$ sinyal yolunun aktivasyonunda artış; süperoksit dismutaz (SOD), katalaz ve peroksidaz enzim düzeylerinde düşüş gözlenmiştir. Arsenik maruziyetinin ardından Lactobacillus acidophilus, L. rhamnosus, Bifidobacterium longum, and Bifidobacterium bifidum ve Saccharomyces boulardii içeren bir probiyotik takviyesi alan diğer grupta anlamlı bir farkla lipit peroksidasyon ürünlerinde azalma bildirilmiştir ve probiyotik alan grupta SOD, katalaz ve peroksidaz enzim aktiviteleri korunmuştur. Arsenik maruziyetinin aynı zamanda menstrüel döngüde bozulmaya ve foliküler atreziye sebep olarak üreme fonksiyonlarını olumsuz etkilediği gözlenmiştir. Probiyotik takviyesinin bu etkileri tersine çevirdiği ve ağır metal maruziyetine karşı üreme fonksiyonlarının korunmasını sağladığı bildirilmiştir. ${ }^{30}$ L. acidophilus, L. rhamnosus, B. Longum ve S. Boulardii türlerinin arsenik toksisitesine ${ }^{30}, \quad$ L. acidophilus Rosell, $L$. rhamnosus Rosell ve B. longum Rosell türlerinin kadmiyuma ${ }^{31,32}, B$. Coagulans ve $L$. plantarum'un civaya $^{33}$, L. bulgaricus'un kurşuna $^{34}$ L. $\quad$ plantarum'un krom toksisitesine karşı etkili olduğu fareler üzerinde yapılan çalışmalarda gösterilmiştir.

Probiyotiklerin ağır metal toksisitesini azaltma potansiyelini araștırmıș olan iki insan çalıșması vardır. Tanzanya'da hamile kadınlar ve çocuklar üzerinde yapılmış çalışmada L. Rhamnosus GR-1 (LGR1)'in arsenik ve civa emilimine karşı koruma sağladığı gösterilmiştir. Fakat diğer kan metal seviyelerinde anlaml bir fark bulunamamıştır. ${ }^{31}$

Diğer çalışma çinko, kadmiyum ve kurşunun fazla miktarda olduğu, toprakta ve pirinçte oldukça yüksek seviyede kadmiyum tespit edilmiş madencilik bölgesinde yaşayan 60 kişinin katılımıyla yapılmış çiftkör plasebo kontrollü bir çalışmadır. Katılımclara $1 \times 10^{9}$ CFU L. plantarum CCFM8610 iki ay boyunca günlük olarak verilmiştir. Probiyotik alan grupta kan kadmiyum seviyelerinde anlamlı bir düşüș olduğu saptanırken, plasebo grubunda böyle bir etki gözlenmemiştir. L. plantarum CCFM8610 uygulamasından sonra karaciğer kadmiyum seviyelerinde ve böbrekte kadmiyum birikiminin önemli ölçüde düștüğü gözlenmiștir. Çalıșmanın bir diğer kısmı olan farelerde L. plantarum CCFM8610 uygulamasının, hepatik safra asit sentezi, glutatyon üretimi ve dışkıda safta asiti atımını arttırdığı gösterilmiş ve bu düzenleyici etkilerin antibiyotik muamelesiyle tersine çevrilerek etkilerin 
mikrobiyota

gösterilmiştir. ${ }^{35}$

kaynaklı

olduğu

\section{Sonuç ve Öneriler}

Modern yaşamla birlikte ağır metallere maruziyet, intestinal mikrobiyotada önemli değişikliklere sebep olmaktadır. Konağın genetik, epigenetik ve fenotipik durum ve/veya yerleşik intestinal mikrobiyota; çevresel kimyasalların absorpsiyon, dağılım, metabolizma ve atılımını etkilemektedir. İntestinal mikrobiyal topluluğunda değișimin ne yönde olduğu, hangi metabolitlerin etkilendiği ve mikrobiyotadaki bu değişikliklerin metabolik profilimizi nasıl etkilediğini tamamen aydınlatabilmek için daha kapsamlı çalışmalara ihtiyaç vardır. Ağır metallerin sebep olduğu mikrobiyotaki bozukluklar oksidatif stres, karaciğer hasarı, obezite gibi çeşitli sağlık sorunlarını beraberinde getirebilir. Probiyotikler ile yapılan diyet takviyeleri ise gida kaynaklı kirleticilerin neden olduğu hasarı etkin bir şekilde azaltmak ve mikrobiyotayı yeniden dengelemek için umut verici gözükmektedir. Probiyotiklerin ağır metal maruziyetine etkisi suşa, doza bağımlı ve metale özgü olabilmektedir. Probiyotiklere ilișkin araştırmaların çoğu, hayvan modelleri üzerinde yapılmıştır. Probiyotiklerin ağır metal maruziyetinde teröpatik olarak kullanılmasında önemli etkisinin olabileceği düşünülmektedir.

Yazar katkısı: KB literatür taraması yaptı ve makaleyi hazırladı. AA derlemeyi revize etti.

Çıkar çatışması: Bu çalışma için herhangi bir mali destek alınmamıştır.

Mali destek: Yazarlar arasında herhangi bir çıkar çatışması bulunmamaktadır.

\section{Kaynaklar}

1. Jaishankar $M$, Tseten $T$, Anbalagan N, Mathew BB, Beeregowda KN. Toxicity, mechanism and health effects of some heavy metals. Interdiscip Toxicol. 2014; 7(2): 60-72.
2. Rehman K, Fatima F, Waheed I, Akash MSH. Prevalence of exposure of heavy metals and their impact on health consequences. J Cell Biochem. 2018; 119(1): 157-184.

3. Yılmaz K, Altındiş M. Sindirim sistemi mikrobiyotası ve fekal transplantasyon. Nobel Med 2017; 13(1): 9-15.

4. Koçak T, Şanlıer N. Mikrobesin öğeleri ve mikrobiyota etkileşimi. Gümüşhane Üniversitesi Sağlık Bilimleri Dergisi. 2017; 6(4): 290-302.

5. Richardson JB, Dancy BCR, Horton CL, et al. Exposure to toxic metals triggers unique responses from the rat gut microbiota. Sci Rep. 2018; 8(1): 6578.

6. Lu K, Abo RP, Schlieper KA, Graffam ME. Levine S, Wishnok JS, Swenberg JA, Tannenbaum SR, Fox JG. Arsenic exposure perturbs the gut microbiome and its metabolic profile in mice: an integrated metagenomics and metabolomics analysis. Environmental Health Perspectives. 2014; 122(3): 284291.

7. Lu K, Abo RP, Schlieper KA, Graffam ME, Levine, S, Wishnok, JS, Swenberg JA, Tannenbaum SR, Fox JG. Arsenic exposure perturbs the gut microbiome and its metabolic profile in mice: an integrated metagenomics and metabolomics analysis. Environmental Health Perspectives. 2014; 122(3): 284291.

8. Lu K, Mahbub R, Cable PH, Ru H, Parry NM, Bodnar WM, Wishnok JS, Styblo M, Swenberg JA, Fox JG, Tannenbaum SR. Gut microbiome phenotypes driven by host genetics affect arsenic metabolism. Chem Res Toxicol 2014; 27: 172-174.

9. Guo X, Liu S, Wang Z, Zhang XX, Li M, Wu B. Metagenomic profiles and antibiotic resistance genes in gut microbiota of mice exposed to arsenic and iron. Chemosphere. 2014; 112: 1-8.

10. Dahan D, Jude BA, Lamendella R, Keesing F, Perron GG. Exposure to arsenic alters the microbiome of larval zebrafish. Frontiers in Microbiology. 2018; 9: 1323. 
11. Gao B, Chi L, Mahbub R, Bian X, Tu P, Ru $\mathrm{H}, \mathrm{Lu} \mathrm{K}$. Multi-omics reveals that lead exposure disturbs gut microbiome development, key metabolites, and metabolic pathways. Chem Res Toxicol. 2017; 30(4): 996-1005. doi: 10.1021/acs.chemrestox.6b00401.

12. Xia J, Lu L, Jin C, Wang S, Zhou J, Ni Y, Fu $\mathrm{Z}$, Jin Y. Effects of short term lead exposure on gut microbiota and hepatic metabolism in adult zebrafish. Comp Biochem Physiol C Toxicol Pharmacol 2018; 209: 1-8.

13. Wu J, Wen XW, Faulk C, Boehnke K, Zhang H, Dolinoy DC, Xi C. Perinatal lead exposure alters gut microbiota composition and results in sex-specific bodyweight increases in adult mice. Toxicol Sci. 2016; 151(2): 324-333.

14. Breton J, Massart $S$, Vandamme $P$, De Brandt E, Pot B, Foligné B. Ecotoxicology inside the gut: impact of heavy metals on the mouse microbiome. BMC Pharmacol Toxicol. 2013; 14: 62.

15. Cani PD, Everard A. Akkermansia muciniphila: a novel target controlling obesity, type 2 diabetes and inflammation. Medecine Sciences: M/S. 2014; 30(2): 125-127.

16. Li Y, Liu K, Shen J, Liu Y. Wheat bran intake can attenuate chronic cadmium toxicity in mice gut microbiota. Food Funct 2016; 7(8): 3524-3530.

17. Zhang S, Jin Y, Zeng Z, Liu Z, Fu Z. Subchronic exposure of mice to cadmium perturbs their hepatic energy metabolism and gut microbiome. chem Res Toxicol. 2015; 28(10): 2000-2009.

18. Tinkov AA, Gritsenko VA, Skalnaya MG, Cherkasov SV, Aaseth J, Skalny AV. Gut as a target for cadmium toxicity. Environ Pollut. 2018; 235: 429-434.

19. Plunkett $\mathrm{CH}$, Nagler CR. The influence of the microbiome on allergic sensitization to food. J Immunol. 2017; 198(2): 581589.

20. Ba Q, Li M, Chen P, et al. Sex-dependent effects of cadmium exposure in early life on gut microbiota and fat accumulation in mice. Environmental Health Perspectives. 2017; 125(3): 437-446.

21. Jafarpour, D.; Shekarforoush, S. S.; Ghaisari, H. R.; Nazifi, S.; Sajedianfard, J. Impact of synbiotic diets including inulin, bacillus coagulans and lactobacillus plantarum on intestinal microbiota of rat exposed to cadmium and mercury. Vet Sci Develop 2015; 5: 2.

22. Wu G, Xiao X, Feng P, Xie F, Yu Z, Yuan W,et al. Gut remediation: A potential approach to reducing chromium accumulation using Lactobacillus plantarum TW1-1. Sci Rep 2017; 7: 15000.

23. Gillois $K$, Lévêque $M$, Théodorou $V$, Robert H, Mercier-bonin m. mucus: an underestimated gut target for environmental pollutants and food additives. Microorganisms. 2018; 6(2): 53.

24. Zhai Q, Li T, Yu L, Xiao Y, Feng S, Wu J, Zhao J, Zhang $\mathrm{H}$, Chen W. Effects of subchronic oral toxic metal exposure on the intestinal microbiota of mice. Sci Bull 2017; 62(12): 831-840.

25. Richardson JB, Dancy BCR, Horton CL, et al. Exposure to toxic metals triggers unique responses from the rat gut microbiota. Sci Rep. 2018;8(1):6578.

26. Rosenfeld CS. Gut dysbiosis in animals due to environmental chemical exposures. front cell infect Microbiol. 2017; 7: 396.

27. Feng P, Ye Z, Kakade A, Virk AK, Li X, Liu P. A Review on gut remediation of selected environmental contaminants: possible roles of probiotics and gut microbiota. Nutrients. 2018; 11(1): 22.

28. Zhai Q, Wang G, Zhao J, Zhao, J, Liu X, Tian $\mathrm{F}$, Zhang H, Chen W. Protective effects of Lactobacillus plantarum CCFM8610 against acute cadmium toxicity in mice. Appl Environ Microbiol. 2013; 79(5): 1508-1515.

29. Zhai Q, Wang G, Zhao J, Liu X, Narbad A, Chen YQ, Zhang H, Tian F, Chen W. Protective effects of Lactobacillus plantarum CCFM8610 against chronic 
cadmium toxicity in mice indicate routes of protection besides intestinal sequestration. Appl Environ Microbiol. 2014; 80(13): 4063-71.

30. Chattopadhyay S, Khatun S, Maity M, Jana S, Perveen H, Dash M, Dey A, Jana LR, Maity PP. Association of vitamin B12, lactate dehydrogenase, and regulation of $\mathrm{nf}-\kappa \mathrm{b}$ in the mitigation of sodium arsenite-induced ros generation in uterine tissue by commercially available probiotics. Probiotics Antimicrob Proteins. 2019; 11(1): 30-42.

31. Jama AM, Mitic-Culafic D, Kolarevic S Durasevic SF, Knezevic-Vukcevic J. Protective effect of probiotic bacteria against cadmium-induced genotoxicity in rat hepatocytes in vivo and in vitro. Arch Biol Sci 2012; 64(3): 1197-1206.

32. Djurasevic $S$, Jama A, Jasnic N, Vujovic $P$, Jovanovic M, Mitic-Culafic D, KnezevicVukcevic J, Cakic-Milosevic M, Ilijevic K, Djordjevic J. The protective effects of probiotic bacteria on cadmium toxicity in rats. J Med Food. 2017; 20(2): 189-196.

33. Majlesi M, Shekarforoush SS, Ghaisari HR, Nazifi S, Sajedianfard J, Eskandari MH. Effect of probiotic bacillus coagulans and lactobacillus plantarum on alleviation of mercury toxicity in rat. Probiotics Antimicrob Proteins. 2017; 9(3): 300-309.

34. Li B, Jin D, Yu S, Etareri Evivie S, Muhammad Z, Huo G, Liu F. In Vitro and In Vivo Evaluation of Lactobacillus delbrueckii subsp. bulgaricus KLDS1.0207 for the Alleviative Effect on Lead Toxicity. Nutrients. 2017; 9(8): 845.

35. Zhai Q, Liu Y, Wang C, Zhao J, Zhang $H$, Tian F, Lee YK, Chen W. Increased cadmium excretion due to oral administration of lactobacillus plantarum strains by regulating enterohepatic circulation in mice. J Agric Food Chem. 2019; 67(14): 3956-3965.

36. Dheer R, Patterson J, Dudash M, et al. Arsenic induces structural and compositional colonic microbiome change and promotes host nitrogen and amino acid metabolism. Toxicol Appl Pharmacol. 2015; 289(3): 397-408.

37. Chi L, Bian X, Gao B, Ru H, Tu P, Lu K. SexSpecific Effects of arsenic exposure on the trajectory and function of the gut microbiome. Chem Res Toxicol. 2016; 29(6): 949-51.

38. Calatayud M, Vélez D, Devesa V. Metabolism of inorganic arsenic in intestinal epithelial cell lines. Chemical Research in Toxicology. 2012; 25(11): 2402-2411.

39. Liu Y, Li Y, Liu K, Shen J. Exposing to cadmium stress cause profound toxic effect on microbiota of the mice intestinal tract. PLoS One. 2014 ;9(2): e85323.

40. Fazeli M, Hassanzadeh P, Alaei S. Cadmium chloride exhibits a profound toxic effect on bacterial microflora of the mice gastrointestinal tract. Hum Exp Toxicol. 2011; 30(2): 15 